\title{
MULTIFUNCTIONAL LANDSCAPES AND SOCIOECONOMIC IMPACTS: A CASE STUDY ON PRODUCTIVE SECTORS OF RANCHERÍA RIVER BASIN, GUAJIRA, COLOMBIA
}

\author{
CLAUDIA L. LONDOÑO CASTAÑEDA, MIGUEL ANGEL DIAZ, YOMAIRA DEVIA, \\ JUAN SEBASTIAN BALLEN \& JUAN DAVID BARRIOS \\ University Santo Tomas, Colombia
}

\begin{abstract}
This study quantifies the economic contributions of the different productive sectors in the Ranchería River basin from 1980 to the present, according to official information available from the DNP, La Guajira's Chamber of Commerce, and other sources. The study provides a comparative analysis of the economic benefits derived by direct users of the Ranchería River basin in the Colombian Guajira region, contrasting the economic valuation of direct uses by agricultural, livestock, and mining activities with the main socioeconomic indicators (e.g. GDP, poverty, unsatisfied basic needs) of the basin's municipalities. The economic valuation was made with the market price methodology using information by subsectors of each one of the branches of economic activity. For a better understanding of the relationship between territorial dynamics and the basin's economy, the study presents some maps capturing vegetation cover and land use in the basin area using available archival geographic information systems, mainly from the Colombian Geographic Institute (IGAC), over different periods. Keywords: multifunctional landscapes, economic valuation, market prices, ethnic groups.
\end{abstract}

\section{INTRODUCTION}

The department of La Guajira is one of the most remote regions of Colombia. It is one of the most deserted regions of the country and it is home to the Ranchería River basin, with an area of approximately $4,000 \mathrm{~km}^{2}$. The river begins to the south of the department in the páramo of Chirigua, extending to more than 3,800 metres above sea level through the snowy mountain range of Santa Marta, and ends at the Caribbean Sea after a $248 \mathrm{~km}$ route. The Ranchería River, from its source to its mouth, exhibits a diverse number of biomes, including ecosystems of páramo, mangrove, tropical dry forest, and subtropical thorn scrub (Otero [2]).

La Guajira has one of the greatest water deficits in Colombia because it is in a desert region with high rates of evapotranspiration. Additionally, climatic variability caused by phenomena, such as "La Niña" or "El Niño", increase the region's vulnerability. In recent years, the Guajira has experienced a "humanitarian" crisis due to both the shortage and the poor quality of water in the region. This situation has left cases of malnutrition and decreased access to potable water with inadequate availability and quality. This has caused high rates of mortality and morbidity in the indigenous Wayuu population, and expanded the department's poverty indices, leaving basic needs unsatisfied and reducing possibilities for community development (Defensoria del Pueblo [3]).

Since the 1980s, this department has hosted activities of the coal complex "Cerrejon", with a mine located in the central zone of the department of La Guajira (Fig. 1), in the jurisdiction of the municipalities of Barrancas, Fonseca, Hatonuevo, Albania, Maicao, and Uribía. The total area of the mining concession covers an approximate length of $50 \mathrm{~km}$ along both banks of the Ranchería River. Coal deposits are located in an area of 69,000 hectares, close to $3.3 \%$ of the department's area, within which two zones are identified: Central Zone 


\section{LOCATION OF RANCHERIA RIVER BASIN}
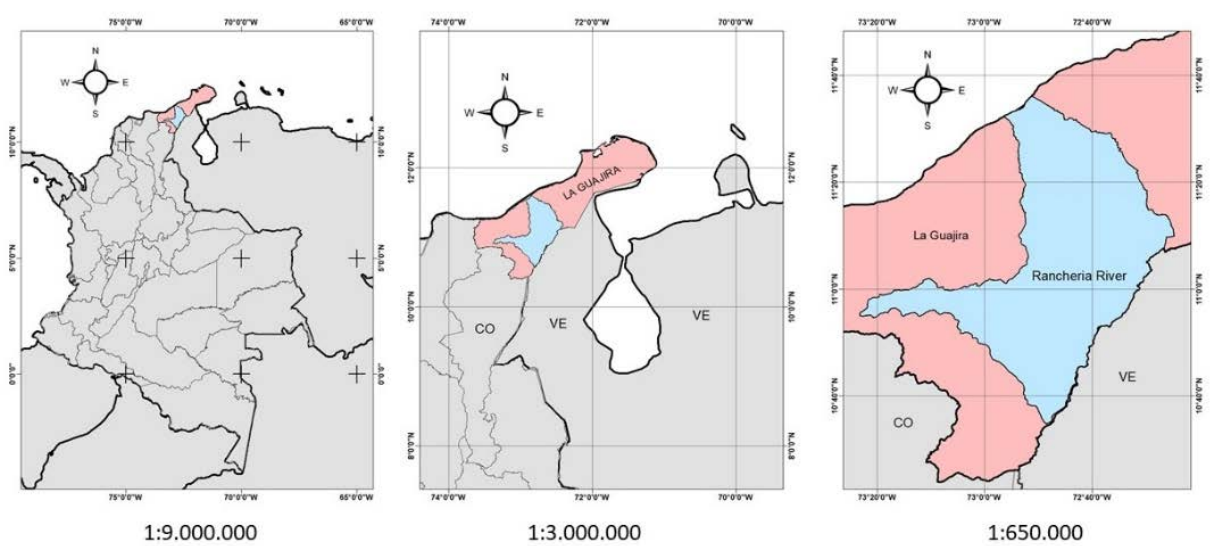

Leyend

$\square$ Basin - Rancheria River $\square$ La Guajira $\square$ Departmental limit $\square$ National limit

Figure 1: Location of the Ranchería River basin. (Source: Author, data SIGOT [5], [6].)

and Northern Zone or New Mining Areas (Pin, Oreganal, and Zona South) (Corpoguajira [1], Gualdrón Acosta [4]).

Similarly, the region has economic activities in agricultural, livestock, and industrial sectors. These economic activities should have allowed the region to evolve along with the country's other departments. However, growing cases of diseases associated with the water quality and alarming cases of deaths among the indigenous and Wayuu communities due to malnutrition have reactivated a conflict that has been constant in the territory since the beginning of the Cerrejon operation. This paper presents the main socioeconomic indicators that, allows observing in macroeconomic figures, the main indicators used to interpret the general conditions of a population.

\section{METHODOLOGY}

This study is a comparative analysis of the economic benefits derived from productive sectors of direct users of the Ranchería River basin in the Colombian Guajira. It contrasts the economic valuation of direct uses by agricultural, livestock, and mining activities with the main socioeconomic indicators (e.g., GDP, poverty, unsatisfied basic needs) of the basin's municipalities. The economic contributions of the different productive sectors from 1980 to the present were quantified according to official information available from the DNP, La Guajira's Chamber of Commerce, and Official Publications of the Republic Bank on the Agricultural and Livestock Census. We used the historic data from Republic Bank of TRM to translate the values of pesos to dollars.

The economic valuation was carried out using the market price methodology, with information from subsectors of the main branches of economic activity associated with the use of the basin. The information from the productive sectors was not obtained in a uniform way for the basin's municipalities, because there was imprecise information from the agricultural and livestock sectors. However, it is necessary to clarify that generally there is low production of these sectors in the region due to the basin's climatic conditions and the difficulties related to accessing water, the fact that the region has been historically ignored. 
The official documents of the agricultural and livestock sector were evaluated. These included: Departmental Accounts of Colombia, DANE, 1980-1989; Analysis of Agricultural Situation, Regional Unit of Agricultural Planning UPRA, Ministry of Agriculture, 1995; Analysis of Situation, UPRA, 1996; Statistical Yearbook of the Agricultural Sector, Ministry of Environment and Rural Development, 1993-2004. Statistical Yearbook of the Agricultural and Fisheries Sector, Ministry of Environment and Rural Development, 2010; and National Agricultural and Livestock Census 2014, Ministry of Agriculture [7]-[13].

As a temporary baseline for economic valuation, the year 1980 was studied. This year was chosen because the mining concession was made in 1984. Also in that decade, areas were designated as indigenous reservation and/or protected areas. For a better understanding of the relationship between territorial dynamics and the basin's economy, this study presents some maps with characteristics of vegetation cover and the use of the basin's land by analysing files available in geographic information systems. We used the Colombian Geographical Institute, Government Information System (SIGOT) [5]; Identification of priority areas and conservation approaches and land management in the operational zones of ECOPETROL; and a study carried out at a scale of 1:30,000 by the Alexander Von Humboldt Institute in 2015 (IIAVH [14]). Cartographic information was used to characterise multifunctional landscapes in the Ranchería River basin's area of influence to identify the use and coverage of the soil associated with various productive sectors of the study.

\section{RESEARCH RESULTS}

The river's jurisdiction includes the municipalities of San Juan del Cesar, Fonseca, Distracción, Barrancas, Hato Nuevo, Albania, Riohacha, Manaure and Maicao. The basin was mainly stocked with water from the runoffs of the Sierra Nevada de Santa Marta; however, it receives contributions from tributaries from the Perijá and Serrania (Otero [2]).

\subsection{Multifunctional landscapes, coverage, and land use}

The basin's territory has traditionally been inhabited by peasants, settlers, mestizos, afroColombians from the region, and different indigenous populations. These include Wiwa, Yulpa, Wayuu, Kogui, and Arhuacos (Corpoguajira [1]).

\subsubsection{Ethnic groups and territory}

According to data from the National Population and Housing Census of the DANE, during the years 1973, 1985, and 2005, the population dynamics in the department were imminently rural in 1973. The indigenous communities obtained collective property rights in 1984 and they have been occupying the territory since before the arrival of the Spanish. They have settlements in the lower part of the basin for the Wayuu community, and in the high zone Wiwa, Yulpa, Kogui, and Arhuacos settlements are located in the foothills of the Sierra Nevada de Santa Marta [15]-[17].

\subsubsection{Ecosystems, coverage and land use in the Ranchería River basin}

According to the IIAVH study (1:30,000), Fig. 2 indicates that the red color signifies human's settlements and mining area; the orange represents agricultural zones. In Fig. 3, dark green are agriculture, yellow are mangrove, orange are the small natural forest area, red are suburban and settlements. Areas for cattle grazing make up $24.2 \%$ of the region. Crops account for $14 \%$, while $11.8 \%$ of area has natural forests, and $1.4 \%$ is a river or coastal ecosystem. Data indicate that $35.4 \%$ of the area has arid xerophytes, which implies that these areas are not usable for agriculture and livestock. In general, the areas that are in their natural 


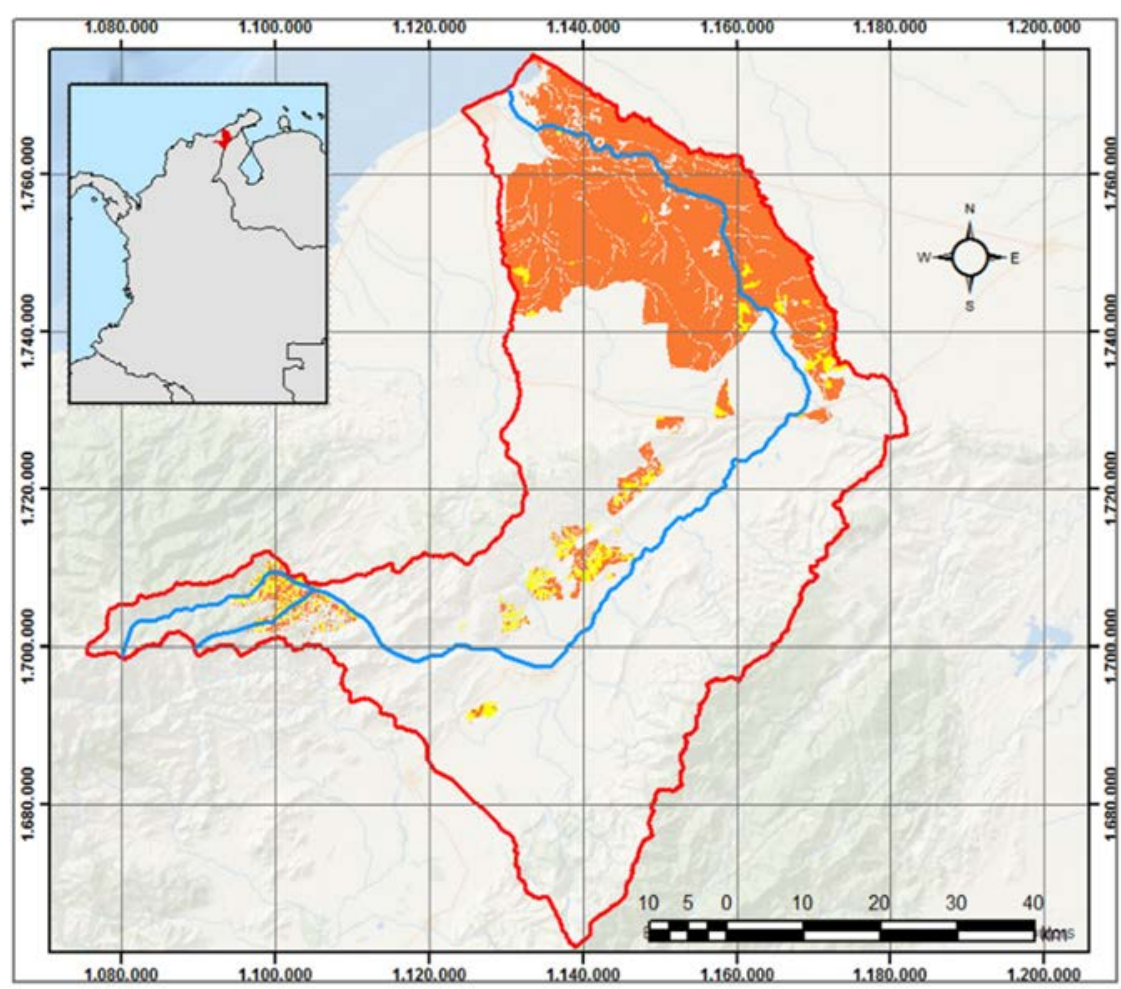

Settlements and indigenous reserves at Rio Rancheria basin

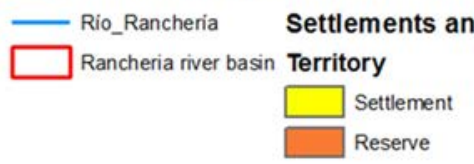

Figure 2: Indigenous reserves, Ranchería River basin. (Source: SIGOT [5].)

state make up 13.1\% (includes river and wetlands 0.7, mangroves 0.7, marine and costal ecosystems 0.7 , paramo 0.7 , different forest categories 10.2 and $53.9 \%$, depending on different grades of transformation.

\subsection{Main socio-economic indicators}

\subsubsection{Demographic dynamics}

The last population census in 2005 determined that $44.9 \%$ was indigenous; and inhabitants in the region live in the municipal capitals and 48.1\% reside in the rural area. From 1980 to the present, the population has increased in the municipalities surrounding the Ranchería River. Municipalities such as Albania, Distracción, and Hato Nuevo are territories in which settlers who worked in the Cerrejon mine were settled, and their respective populations have increased since the 1990s. In the 1973 census, there were only six municipalities: Riohacha, Barrancas, Fonseca, Maicao, San Juan Del Cesar, Uribía, and Villanueva; there are currently 14. 

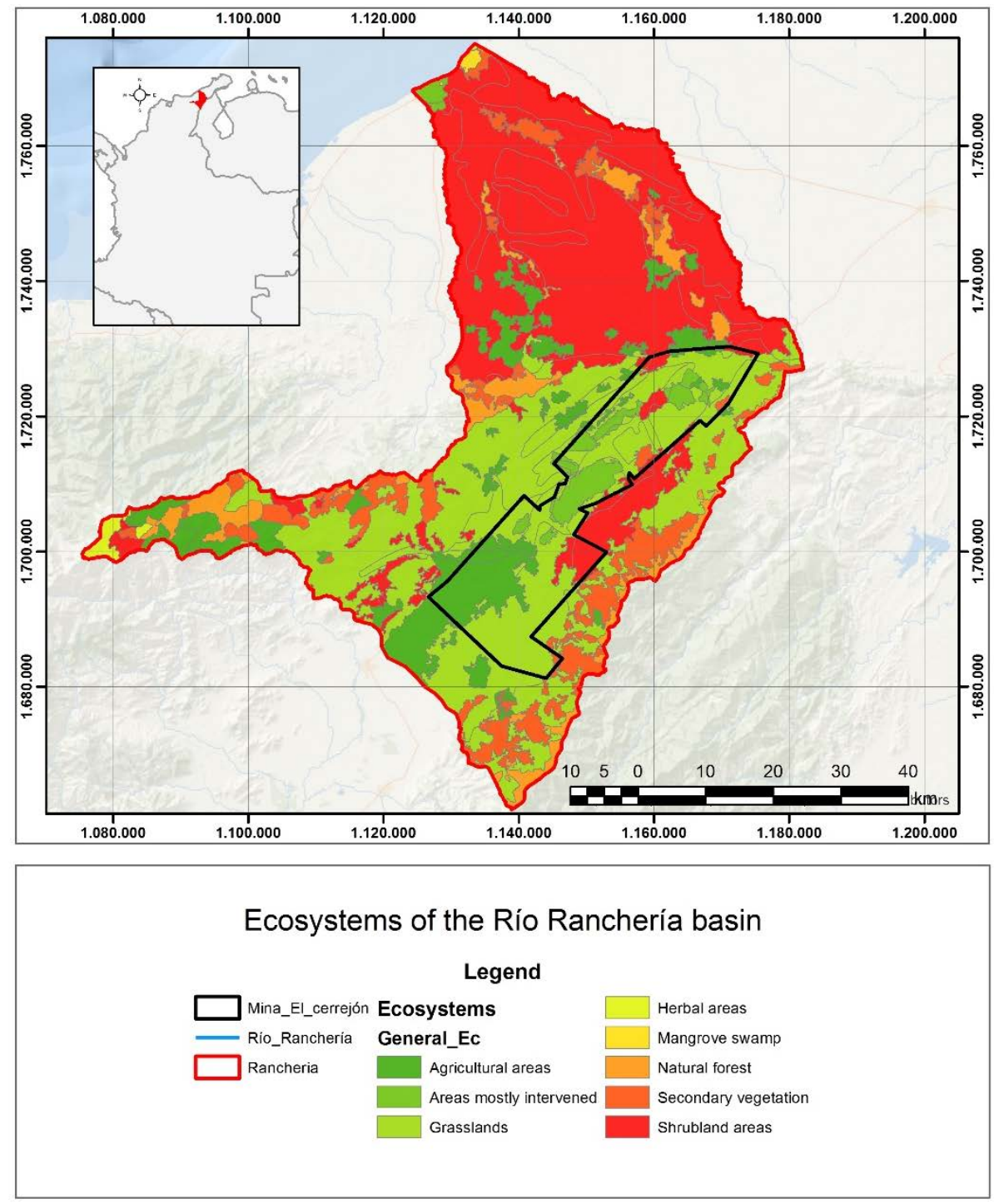

Figure 3: Ecosystems, settlements and agriculture. (Source: IIAVH [14].)

\subsubsection{GDP}

The region's general lag can be seen by analysing the department's GDP per capita, and comparing it with that of the country. The important resources the territory provided as royalties from the mining sector do not seem to generate economic welfare in the area directly influencing the project.

\subsubsection{Poverty lines}

With respect to poverty lines, the data consulted in official sources allow us to observe that La Guajira remains below the national line, the nation's ultimate poverty indicator. This 
situation has mainly affected the indigenous population settled in rural areas. For example, the infant mortality rate of the indigenous population, according to the 2005 census, was $42.3 \%$; the child mortality rate was $59.9 \%$; and the youth illiteracy rate was $47.8 \%$. Similarly, in the case of "Extreme Poverty Line", the region always presents results well below the national average.

\subsubsection{Unsatisfied basic needs, NBI}

A large portion of Guajira's population is considered to be in a situation of misery. The principal aspects of unsatisfied needs of Guajira's population include the lack of access to water, the lack of basic housing services such as aqueducts and sewerage, and poor school attendance. In general, all the dimensions evaluated in this indicator provided bad results in this territory. It should be noted that in the 1973, 1985, 1993, and 2005 censuses, the highest percentage of NBI is presented by the municipality of Uribía, with $97.91 \%$. This municipality is outside the Ranchería basin, the country's most deserted area, and populated exclusively by Wayuu community, who have had a reserve there since 1984. In that same year, the reserve was declared legal after the mining concession. The NBI for Manaure was $88.88 \%$, La Jagua del Pinar 72.88\%, Dibuya 65.5\%, Albania 60.66\%, Maicao 57.01\%, Riohacha 55.68\%, El Molino 54.77\%, Barrancas 52.04\%, Distracción 51.18\% and San Juan del Cesar 44.4\%.

\subsection{Benefits of direct use of the main beneficiary sectors of the Ranchería River}

\subsubsection{Contributions to GDP by activity branches}

Fig. 4 represents the behaviour of value added by activity according to current prices between 2000 and 2015. The activity that most contributes to GDP is mining, followed by tourism, and then the manufacturing industry. It should also be noted that there is almost null participation from the agricultural and livestock sectors, which affects the economic valuation of its benefits.

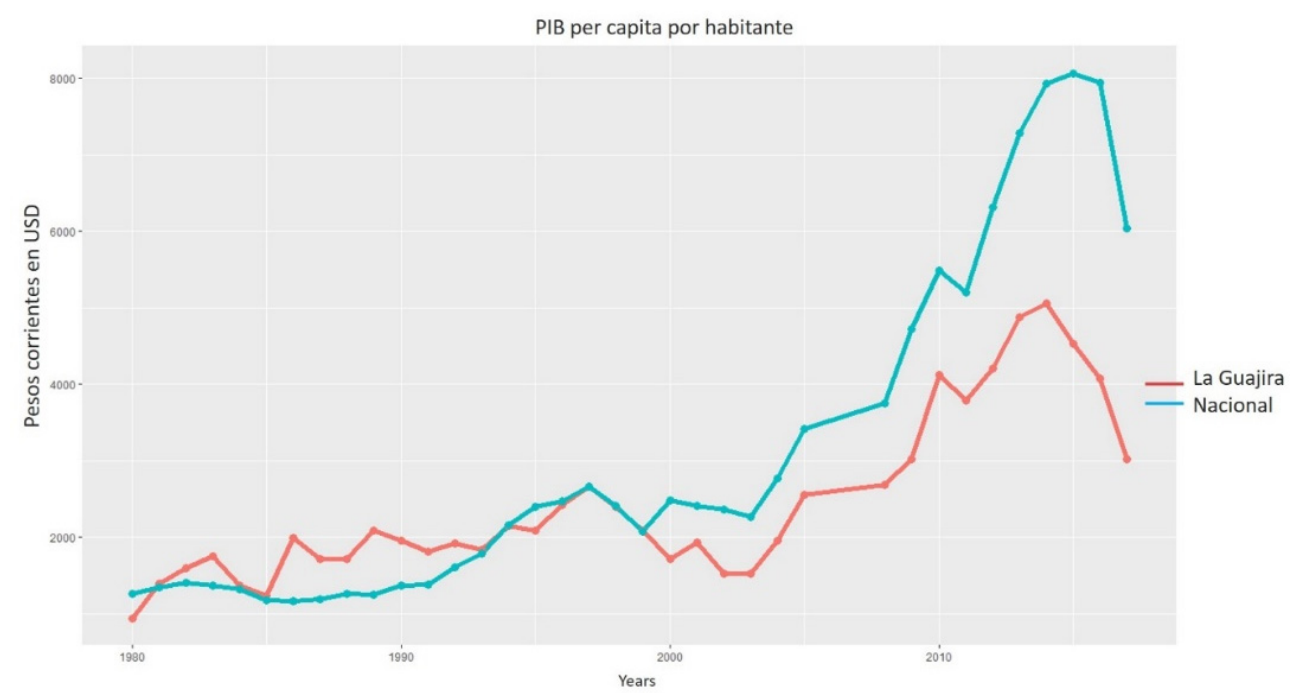

Figure 4: GDP per capita. (Sources: Authors with data from DANE [7].) 


\subsubsection{Agricultural sector}

The economic valuation of the agricultural sector was made with data from throughout the Guajira since data on the 1980s and 1990s are unavailable in a disaggregated manner by municipalities. Information by different entities was aggregated at the regional level and very rarely by municipalities. However, given that the Ranchería River basin is the only possible source of water, we considered that this information represents the valuation of direct use of the sector. According to the data and information obtained with geographical information systems, the area designated for crops accounts for approximately $14 \%$ of the basin's total area, alternating between permanent transitional crops. We can observe that the largest harvested area was present in 2005, 1990, and 1991, respectively. On the other hand, a continuous decrease of crops reflects instability in harvesting crops. Data show that $60 \%$ of the sown area was used for Sorghum and Cotton, which are transitory crops that have better yields compared with permanent crops. At the same time, those agricultural transitory products are those that more are grown in the Guajira and on average according to the available information present the best yields.

\subsubsection{Valuation of agricultural sector}

The value of direct use in agricultural activity is based on the market value method. Under this calculation, the prices paid in the market are multiplied by the quantities produced in tones. The result is the total production of the agricultural sector disaggregated by product, which is multiplied of the average price in the Atlantic area wholesale markets menus taxes. This calculation establishes the sector's market value of the production, to which the margin of contribution to the wholesalers depends on the tax applied in the country. The tax percentage varies, and could be $7 \%, 10 \%, 12 \%, 16 \%$, or exempt.

By product, the transitory crops that contribute most to the value of use are yuca, corn, and rice, respectively. In the case of permanent and semi-permanent crops, green banana and banana contribute the most, respectively. Regarding the taxes or contributions received by the state, we calculated on average $\$ 1,611,718,233$ pesos and in total of the period studied was $\$ 38,681,237,601$. By product, corn, rice, and cotton contribute the most taxes to the state.

\subsubsection{Livestock sector}

To assess the livestock sector in La Guajira, data recorded in ICER economic reports, agricultural surveys, and DANE agricultural yearbooks were evaluated. However, the information presented in these documents for the 1980s and 1990s does not show percentages of cattle herd, stock variation, and milk production because the contribution made by the department to this sector was very low. There is only limited information about cattle slaughter and a few years of milk production available.

Given the available information, the estimation of the direct use valuation of the activity by market prices was made by taking into account the value in pesos of the slaughtered cattle, adding the value in pesos of litres of milk for the years in which activity was registered, and subtracting from this sum the taxes that were generated. The highest income for slaughtered

Table 1: Economic valuation of agricultural production.

\begin{tabular}{|c|c|c|c|}
\hline $\begin{array}{c}\text { Agricultural } \\
\text { production } \\
\text { 1989-2017 }\end{array}$ & Taxes & $\begin{array}{c}\text { Production } \\
\text { taxes }\end{array}$ & US valuation \\
\hline$\$ 1,205,246,205,695$ & $\$ 38,681,237,601$ & $\$ 1,166,564,968,094$ & $\$ 716,235,899$ \\
\hline
\end{tabular}


Table 2: Economic valuation of livestock sector.

\begin{tabular}{|c|c|c|c|}
\hline $\begin{array}{c}\text { A) Value for } \\
\text { livestock slaughter }\end{array}$ & $\begin{array}{c}\text { B) Value for milk } \\
\text { production }\end{array}$ & C) Taxes & A+B-C $=$ Total benefits \\
\hline$\$ 132,724,379,813$ & $\$ 103,361,532,200$ & $\$-$ & $\$ 236,085,912,013$ \\
\hline
\end{tabular}

cattle was presented in 2008, with $\$ 21,368,295,000$; there was a major decrease in 2014 due to the problems of water scarcity occasioned by "child's phenomenon". This resulted in an unsustainable increase in costs for the sector. According to FEDEGAN reports for 2015, there were losses of 6,789 head of cattle due to drought. To date, agreements have been made between the Autonomous Corporation of La Guajira and the Association of Breeders of La Guajira for sustainable development of this sector, focusing on problems related to water and soil restoration.

Milk production income totalled $\$ 103,361,532,200$. Some factors generating low milk production compared with other departments of the Atlantic area include the lack of dual purpose exploitation and water problems in the department.

In Colombia, slaughtered cattle and milk are tax-exempt; for industrial scale large-scale production machinery $2 \%$, for which taxes are not included. The valuation of the livestock sector was $\$ 236,085,912,013$.

\subsubsection{Mining sector}

For the mining sector, information registered by the DANE, the Ministry of Energy, UPME, and the Bank of the Republic were taken from economic reports, yearbooks, and mining bulletins. Information available through the Cerrejon was also consulted.

In Fig. 5, we observe the behaviour of coal production since the beginning of Cerrejon functioning in La Guajira. In that time, there was constant production growth, but a strong decline in 2003, followed by constant growth with small falls in 2010 and 2013. Fig. 5 also shows a decrease in production in recent years. According to current economic reports, it is the second department that generates the largest amount of coal, contributing an average of $43 \%$ of the country's annual coal production. The total production from 1985 to 2016 was $682,546,000$ tons, with an average production of 21,329,562.5 tons.

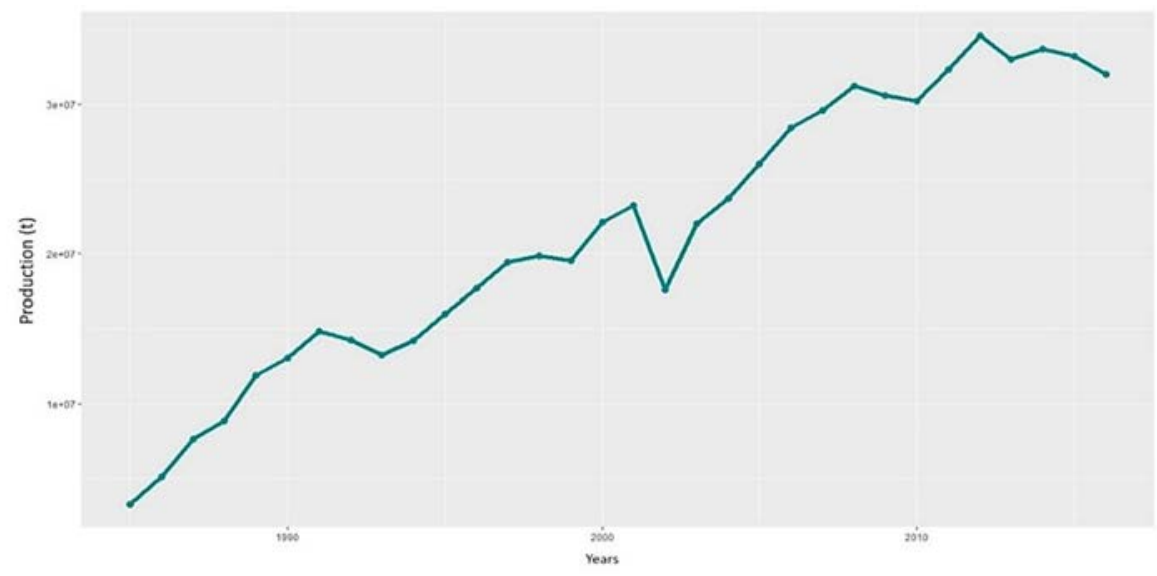

Figure 5: Production in tons of coal in the years 1985-2016. 


\subsubsection{Economic valuation coal mining}

The valuation was carried out by the market price method, taking into account the production in tons of coal, multiplied by the international prices of coal. Contributions for taxes and royalties were subtracted from this number.

The sector generated total production benefits of USD $\$ 34,654,975,360$. The contributions of the sector for taxes totalled USD $\$ 3,450,490,872$. In terms of total royalties, the mining sector contributed USD $\$ 2,828,960,807$. Finally, we calculated that the total benefits derived from the mining activity were USD \$28,375,523,681.

\section{CONCLUSIONS}

La Guajira is a region of great natural wealth, but the agricultural, livestock, port activity, salt extraction, and mining in "El Cerrejón", to mention only a few activities, have not generated the expected social and economic returns. The recent crisis faced by the Wayuu community has highlighted the historic neglect suffered by this department at the hands of state authorities and society as a whole. Resource exploitation has had negative environmental and social impacts on the region, including declining biodiversity, shrinking bodies of water, increasing air, soil, and water pollution, and social deterioration in the communities and inhabitants of the region.

The most important company in the region, the "El Cerrejón" coal-mining complex, is in the department of La Guajira's central region, covering a total length of approximately $50 \mathrm{~km}$ along both sides of the Ranchería River, it has operated since 1984. These are the largest open-pit mines in the world, producing 32 million tons of coal per year, which

Table 3: Economic valuation of coal between 1985 and 2016.

\begin{tabular}{|c|c|c|c|c|}
\hline $\begin{array}{c}\text { Production } \\
\text { (t) }\end{array}$ & $\begin{array}{c}\text { Production in } \\
\text { USD }\end{array}$ & Royalties USD & Taxes USD & $\begin{array}{c}\text { Valoración } \\
\text { USD }\end{array}$ \\
\hline $682,546,000$ & $\$ 34,654,975,360$ & $\$ 2,828,960,807$ & $\$ 3,450,490,872$ & $\$ 28,375,523,681$ \\
\hline
\end{tabular}

Table 4: Total benefits derived from the direct use of the agricultural, livestock and mining sectors, 1989-2017.

\begin{tabular}{|c|c|c|c|c|}
\hline & \multicolumn{3}{|c|}{ Sector } & Total \\
\cline { 2 - 5 } & Agriculture & Livestock & Mining & \\
\hline $\begin{array}{c}\text { Production } \\
\text { value } \\
\text { (USD) }\end{array}$ & $\$ 742,251,068.81$ & $\$ 172,589,569$ & $\$ 34,654,975,360$ & $\$ 35,569,815,998$ \\
\hline $\begin{array}{c}\text { Average } \\
\text { production } \\
\text { value } \\
\text { (USD) }\end{array}$ & $\$ 30,927,127.87$ & $\$ 13,276,121$ & $\$ 1,082,967,980$ & \\
\hline $\begin{array}{c}\text { Taxes and } \\
\text { royalties } \\
\text { (USD) }\end{array}$ & $\$ 26,015,169.81$ & & $\$ 6,279,451,678.82$ & $\$ 6,305,466,848.62$ \\
\hline $\begin{array}{c}\text { Economic } \\
\text { valuation } \\
\text { of direct } \\
\text { use (USD) }\end{array}$ & $\$ 716,235,899$ & $\$ 172,589,569$ & $\$ 28,375,523,681$ & $\$ 29,264,349,149$ \\
\hline
\end{tabular}




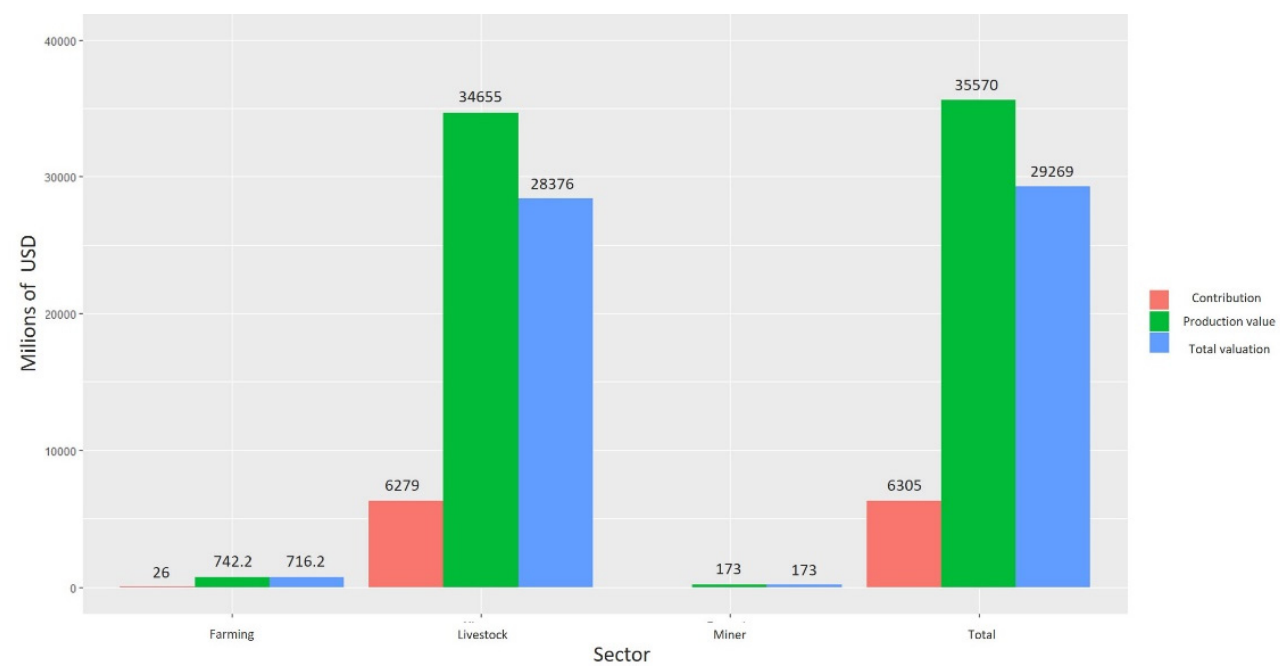

Figure 6: Benefits by sector.

represents $50 \%$ of Colombia's coal exports and 55\% of La Guajira's GDP. The recent crisis in the region with the mining company has been fueled by the water supply and frequent demands for better water management by the area's indigenous communities and the local population. The natural wealth of the region and its economic contributions from important mining activities contrast with the alarming poverty figures and the high morbidity and mortality rates of its indigenous population, representing $46.5 \%$ of the total population.

\section{ACKNOWLEDGEMENTS}

To Gregoria Fonseca and Fernando Prieto in Corpoguajira, for their willingness to share technical information and support information management in the region. To professors and executives of the Faculty of Environmental Engineering of the Santo Tomás University, Bogotá, for supporting the management of resources and providing the conditions that enable the realisation of research relevant to the country's problems.

\section{REFERENCES}

[1] Corpoguajira, Diagnostico General Cuenca del Rio Rancheria, Guajira, 2011.

[2] Otero, A., Río Ranchería: Entre la economía, la biodiversidad y la cultura, Banco de la República: Cartagena, Colombia, 2013.

[3] Defensoría del Pueblo, Crisis humanitaria en La Guajira, Defensoría del Pueblo: Bogotá, 2014.

[4] Gualdrón Acosta, R., Hacia la rehabilitación de las tierras intervenidas por la minería a cielo abierto, 2011.

[5] Sistema de Información de Gobierno (SIGOT), Ecosistemas de Colombia, Ministerio de Ambiente y Desarrollo Sostenible: Bogotá, 2018.

[6] R.D. Colombia, Gobernación de la Guajira, 27 Julio 2017, Online. www.laguajira.gov.co/web/.

[7] DANE, Informe de Coyuntura Económica Regional Departamento de La Guajira, Banco de la República: Bogotá, 2010. 
[8] Departamento Administrativo Nacional de Estadistica, DANE, Cuentas Departamentales de Colombia: Bogota, 1980-1989.

[9] Unidad Regional de Planificación Agropecuaria, URPA, Analisis de Coyuntura Agropecuaria, Ministerio de Agricultura: Riohacha, 1995.

[10] Unidad de Planificación Regional Agropecuaria, URPA, Secretaria de Agricultura, Ministerio de Agricultura, Analisis de Coyuntura 1996, Ministerio de Agricultura: Riohacha, 1996.

[11] Dirección de Política Sectorial, Ministerio de Agricultura y Desarrollo Rural, Anuario Estadístico del Sector Agropecuario y Pesquero, Yerimpresos: Bogotá, 2010.

[12] Ministerio de Agricultura y Desarrollo Rural, Anuario Estadístico del Sector Agropecuario, 1993-2004, Editorial Bochica Ltda: Bogotá, 2004.

[13] Ministerio de Agricultura y Desarrollo Rural, Anuario Estadístico del Sector Agropecuario y Pesquero, Yerimpresos: Bogotá, 2010.

[14] Instituto Alexander Von Humboldt (IIAVH), Documento Técnico Selección e Identificacion de áreas prioritarias y aproximaciones de conservación y manejo del territorio en las zonas operativas de Ecopetrol, IIAVH: Bogotá, 2015.

[15] Departamento Administrativo Nacional de Estadistica, DANE, XIV Censo Nacional y III Censo Nacional de Vivienda, Riohacha, 1973.

[16] Departamento Administrativo Nacional de Estadística Regional Caribe, DANE, Anuario Estadístico del Departamento de la Guajira, Riohacha, 1992.

[17] DANE, Estudios de evaluación del censo de 1985, Departamento Nacional de Planeación: Colombia, 1985. 